Linguista: Jurnal IImiah Bahasa, Sastra, dan Pembelajarannya

Vol. 4, No.1, Juni 2020, hal $51-61$

ISSN (print): 2579-8944; ISSN (online): 2579-9037

Avaliable online at: http://e-journal.unipma.ac.id/index.php/linguista

\title{
Penggunaan Contextual Teaching and Learning (CTL) Berbantuan Kartu Kata Untuk Meningkatkan Keterampilan Menulis Pantun Pada Siswa SD
}

\author{
S Suprapto*, V. Teguh Suharto, dan Lulus Irawati \\ ${ }^{1}$ Universitas Muhammadiyah Surakarta, Jl. A. Yani 1 Pabelan Kartasura Surakarta \\ 57102, Indonesia \\ e-mail: * supraptowajong@gmail.com; suharto teguh@unipma.ac.id; \\ lulusirawati@unipma.ac.id
}

\begin{abstract}
Abstrak
Penelitian ini bertujuan untuk memperoleh deskripsi yang jelas tentang penggunaan pendekatan Contextual Teaching and Learning (CTL) Berbantuan Media Kartu Kata Untuk Meningkatkan Keterampilan Menulis Pantun Pada Siswa Kelas V SDN 2 Ngrayun Ponorogo. Metode penelitian yang digunakan adalah Penelitian Tindakan Kelas (PTK). Sumber data yang digunakan adalah informan, peristiwa dan dokumen. Informan dalam penelitian ini adalah kepala sekolah, guru kelas dan siswa kelas $\mathrm{V}$. Peristiwa dalam penelitian ini adalah segala bentuk pembelajaran di dalam dan di luar kelas. Dokumen penelitian ini adalah RPP, silabus, daftar nilai. Tehnik pengumpulan data pada penelitian ini menggunakan wawancara, observasi, dan dokumentasi. Validitas data menggunakan tehnik triangulasi. Hasil belajar menulis pantun yang diperoleh siswa, dapat diketahui bahwa rata-rata skor pada tindakan sebelum siklus adalah 65,1 dengan persentase ketuntasan belajar klasikal sebanyak 35\% kemudian meningkat pada siklus I menjadi 72,3 dengan persentase ketuntasan belajar klasikal sebanyak $60 \%$. Pada siklus II rata-rata skor hasil belajar siswa mengalami peningkatan lagi menjadi 86,35 dengan persentase ketuntasan belajar mencapai $85 \%$. Berdasarkan data yang telah diperoleh, dapat disimpulkan bahwa penggunaan pendekatan CTL berbantuan kartu kata efektif diterapkan dalam pembelajaran menulis pantun karena terbukti mampu meningkatkan keterampilan guru, aktivitas siswa dan keterampilan menulis pantun pada siswa kelas V SDN 2 Ngrayun Ponorogo.
\end{abstract}

Kata kunci: Keterampilan Menulis; Pantun; CTL; Kartu Kata

\section{The Use of Contextual Teaching and Learning (CTL) Approach and Word Card Media to Improve Pantun Writing Skill for The Fifth Grade Students of Public Elementary School}

\begin{abstract}
This study aims to obtain a clear description of the Use of the Contextual Teaching and Learning (CTL) Approach and Word Card Media to Improve Skill Pantun Writing Skills in Fifth Grade Students at SDN 2 Ngrayun Ponorogo. The study was Classroom Action Research (CAR). Data sources were informants, events and documents. The informants of the study were the principal, class teacher and the fifth grade students. The activities investigated were all forms of learning inside and outside the classroom. The research documents were RPP, syllabus, list of students' score. Data collection techniques in this study were using interviews, observation, and documentation. Data verification used was triangulation techniques. The result of
\end{abstract}


learning to write Pantun obtained by students shows that the average score of pre action is 65,1 with the percentage of classical learning completeness by $35 \%$ then increases in the first cycle to 72,3 with the percentage of classical learning completeness by $60 \%$. In the second cycle the average score of student learning outcomes has increased again to 86,35 with the percentage of mastery learning reaching at $85 \%$. In sum, the use of the CTL and word card approach is effectively applied in learning to write pantun, therefore it is proven to be able to improve teacher skills, student activities and poetry writing skills in fifth grade students of SDN 2 Ngrayun Ponorogo.

Keywords: Pantun; Writing skill; CTL; Word Cards

\section{Pendahuluan}

Menulis merupakan kegiatan untuk menyatakan pikiran, perasaan dan pendapat dalam bahasa tulis sehingga dapat dipahami oleh pembaca.. Berkaitan dengan pantun, seseorang akan terampil menulis pantun jika terbiasa praktek dan berlatih sejak kecil.Pantun merupakan salah satu karya sastra klasik yang berkembang sebelum masuknya pengaruh bangsa barat ke Indonesia. Pantun oleh masyarakat Indonesia dipergunakan untuk menyatakan perasaan cinta atau kebencian, nasehat atau pendidikan, dakwah agama, bisnis atau perdagangan, hiburan, propaganda dan lain-lain (Supriyadi, 2016, p. 47). Pantun sudah dimiliki oleh nenek moyang bangsa Indonesia jauh sebelum datangnya kebudayaan Hindu dan Arab. Pantun terdapat hampir merata di seluruh nusantara walaupun diucapkan dalam bahasa daerah.

Pembelajaran menulis pantun disampaikan di kelas $\mathrm{V}$ semester 1 sekolah dasar dengan standar kompetensi: menggali isi dan amanat pantun yang disajikan secara lisan dan tulis dengan tujuan untuk kesenangan, melisankan pantun hasil karya pribadi dengan lafal, intonasi, dan ekspresi yang tepat sebagai bentuk ungkapan diri. Kompetensi dasar yag diharapkan adalah agar siswa dapat membuat pantun anak yang menarik tentang berbagai tema (kesehatan, persahabatan, ketekunan, kepatuhan dan lain-lain) sesuai dengan ciri-ciri pantun. Saat ini, keterampilan siswa dalam menulis pantun sangat rendah. Hasil evaluasi dari 20 siswa kelas V SDN 2 Ngrayun menunjukkan nilai rata-rata siswa adalah 52,70. Rata-rata tersebut belum memenuhi Kriteria Ketuntasan Minimal (KKM) yang telah ditetapkan, yakni 70. Jumlah siswa yang sudah memenuhi KKM baru ada 7 (35\%) sedangkan sejumlah $13(65 \%)$ siswa belum memenuhi KKM.

Kesalahan yang sering dijumpai pada pantun yang dibuat siswa meliputi: ketidaksesuaian dengan syarat pantun dari segi bentuk, ketidaksesuaian pantun dengan syarat pantun dari segi isi dan kesalahan dalam penulisan ejaan dan tanda baca, terlihat bahwa siswa kesulitan dalam memulai pembuatan pantun. Motivasi yang dimiliki siswa untuk membuat pantun juga sangat rendah.Pembelajaran menulis pantun disajikan dengan pola tradisional yang belum memberikan porsi lebih bagi siswa untuk aktif. Metode yang digunakan masih terbatas pada ceramah dan penugasan. Penjelasan pengetahuan tentang pantun, seperti pengertian pantun dan aturan-aturan pantun disampaikan dengan metode klasikal.

Model contextual teaching and learning (CTL) yang diterapkan dalam pembelajaran pantun diharapkan mampu memecahkan permasalahan dalam pembelajaran. Dalam hal ini, guru mengaitkan materi yang diajarkan kepada siswa dengan kehidupan sehari-hari. Menurut (Rusman, 2014, p. 190) melalui pendekatan kontekstual (CTL), mengajar bukan transformasi pengetahuan dari guru kepada siswa dengan menghafal sejumlah konsep-konsep yang sepertinya terlepas dari kehidupan nyata, akan tetapi lebih ditekankan pada upaya memfasilitasi siswa untuk mencari keterampilan bisa hidup (life skills) dari apa yang dipelajari . 
Pembelajaran Kontekstual (CTL) merupakan pendekatan pembelajaran yang mengaitkan antara materi yang dipelajari dengan kehidupan nyata siswa sehari-hari, baik lingkungan keluarga, sekolah, masyarakat, maupun warga negara, dengan tujuan menemukan makna materi tersebut bagi kehidupannya (Rosmayanti, 2010).

Menurut (Hosnan, 2014, p. 297) kelebihan dalam menggunakan model CTL dalam pembelajaran yaitu: (1) pembelajaran lebih bermakna dan nyata, siswa dituntut untuk dapat menangkap hubungan antara pengalaman belajar di sekolah dengan kehidupan nyata. Hal ini sangat penting sebab dengan mengorelasikan materi yang ditemukan dengan kehidupan nyata, materi yang dipelajarinya akan tertanam erat dalam memori dan tidak akan mudah dilupakan; (2) pembelajaran lebih produktif dan mampu menumbuhkan penguatan konsep kepada siswa karena siswa dituntun untuk menemukan pengetahuannya sendiri melalui landasan filosofis kontruktivisme dengan proses mengalami bukan menghafal. Sependapat dengan hal tersebut, (Rifa'i \& Anni, 2011, p. 247) mengungkapkan bahwa dengan menggunakan model CTL dalam pembelajaran, proses belajar mengajar akan lebih konkret, lebih realitis, dan lebih bermakna.

Berdasarkan uraian tersebut, kelebihan menggunakan model CTL dalam pembelajaran yaitu proses pembelajaran menjadi bermakna bagi siswa karena siswa dituntut untuk melakukan proses menemukan pengetahuan barunya sendiri sehingga memorinya tidak akan mudah dilupakan karena siswa tidak menghafal materi semata melainkan berusaha berfikir kritis untuk menemukan sebuah konsep baru dari kegiatan yang dilakukan.

Pembelajaran menulis pantun yang dilakukan belum memanfaatkan media pembelajaranmenjadi penyebab kegagalan siswa dalam menulis pantun. Penyajian pantun dengan media pembelajaran yang jelas dan dekat dengan kehidupan siswa dapat memperjelas dan menarik siswa. (Arsyad, 2014, p. 15) mengemukakan bahwa pemakaian media pembelajaran dalam proses belajar mengajar dapat membangkitkan keinginan dan minat yang baru, membangkitkan motivasi dan rangsangan kegiatan belajar, dan bahkan membawa pengaruh-pengaruh psikologis terhadap siswa.

Untuk meningkatkan keterampilan menulis pantun, guru harus pandai memilih media pembelajaran yang menarik. Pemanfaatan media kartu kata diharapkan dapat membantu efektifitas dan efisiensi pencapaian tujuan pembelajaran menulis pantun. (Hosnan, 2014, p. 111) mendefinisikan bahwa media pembelajaran merupakan media yang penggunaannnya diintegrasikan dengan tujuan dan isi pelajaran yang bermaksud untuk mempertinggi mutu kegiatan belajar mengajar. Media yang digunakan untuk proses penyaluran informasi sesuai tujuan dan isi pelajaran. Pada penelitian ini yaitu media kartu kata (flashcard). Flashcard adalah kartu kecil yang berisi kartu kata, teks, atau tanda simbol yang mengingatkan atau menuntun siswa kepada sesuatu yang berhubungan dengan kartu tersebut.

Kartu kata digunakan untuk mengembangkan ide dalam pembuatan pantun. Setelah mencermati kartu kata akan bermunculan berbagai tanggapan dari siswa yang bisa berupa pertanyaan maupun pernyataan. Siswa kemudian diberi kesempatan untuk menyampaikan kalimat yang menceritakan tentang kartu kata. Dengan bimbingan guru, kalimat-kalimat tersebut dipilih dan disusun sehingga membentuk bagian isi pantun. Siswa kemudian dibimbing untuk menemukan kalimat yang tepat untuk bagian sampiran dengan memperhatikan bunyi akhir pada bagian isi pantun.Media kartu kata dapat menstimulus daya imajinasi dan kreativitas berfikir siswa pada saat proses menulis (Kusumawati, 2016).

Berdasarkan ilustrasi penelitian yang relevan mendorong penulis untuk melakukan penelitian dengan judul "Penggunaan Pendekatan Contextual Teaching and Learning (CTL) Berbantuan Media Kartu Kata Untuk Meningkatkan Keterampilan Menulis Pantun Pada Siswa Kelas V SDN 2 Ngrayun Ponorogo". 


\section{Metode Penelitian}

Classroom Action Research (CAR) atau Penelitian Tindakan Kelas (PTK) digunakan dalam penelitian ini. PTK merupakan suatu pendekatan untuk meningkatkan pendidikan dengan melakukan perubahan terhadapnya dan pembelajaran sebagai konsekuensi terjadi perubahan penelitian ini berisi tindakantindakan yang bertujuan untuk meningkatkan kualitas suatu sistem dan praktik-praktik yang ada dalam sistem tersebut (Susilowati, 2018). Penelitian tindakan kelas adalah penelitian yang dilakukan oleh guru di dalam kelasnya sendiri melalui refleksi diri dengan tujuan untuk memperbaiki kinerjanya sebagai guru sehingga hasil belajar siswa dapat meningkat (Kadarusman \& Cahyono, 2018).

Model Penelitian (Kemmis \& McTaggart, 1988)digunakan dalam penelitian ini berupa untaian-untaian dengan satu perangkat terdiri dari empat komponen, yaitu perencanaan, tindakan, pengamatan, dan refleksi. Keempat komponen yang berupa untaian tersebut dipandang sebagai satu siklus. a) plan(perencanaan), pada tahap perencaan peneliti bersama guru menyimpulkan permasalahan yang sudah di analisis bersama. Peneliti merencanakan tindakan dalam rangka meningkatkan proses pembelajaran dan keterampilan siswa menulis pantun, b) act and observe (Tindakan dan Observasi).

Menurut (Arikunto, 2015, p. 84) memandang komponen sebagai langkah dalam siklus, sehingga mereka menyatukan komponen tindakan (acting) dan pengamatan (observasing) sebagai satu kesatuan. Hasil dari pengamatan dijadikan dasar langkah refleksi.. Rancangan penelitian diantaranya adalah: a) Menyusun Rencana Tindakan (Planning) yaitu menjelaskan tentang apa, mengapa, kapan, di mana, oleh siapa, dan bagaimana tindakan dilakukan; b) Pelaksanaan Tindakan (Acting) yaitu implementasi atau penerapan isi rancangan, yaitu mengenakan rancangan tindakan di kelas; $c$ ) Pengamatan (Observing) yaitu kegiatan pengamatan yang dilakukan pengamat; d0 Refleksi (Reflecting) yaitu kegiatan untuk mengemukakan kembali apa yang sudah dilakukan. Jika ternyata hasilnya belum sesuai dengan yang direncanakan, maka perlu ada rancangan ulang untuk diperbaiki, dimodifikasi, dan jika perlu disusun sekenario baru untuk siklus berikutnya.

Dari terselesaikannya refleksi lalu disusun sebuah modifikasi yang diaktualisasikan dalam bentuk rangkaian tindakan dan pengamatan lagi, begitu seterusnya seperti tampak dalam gambar berikut.

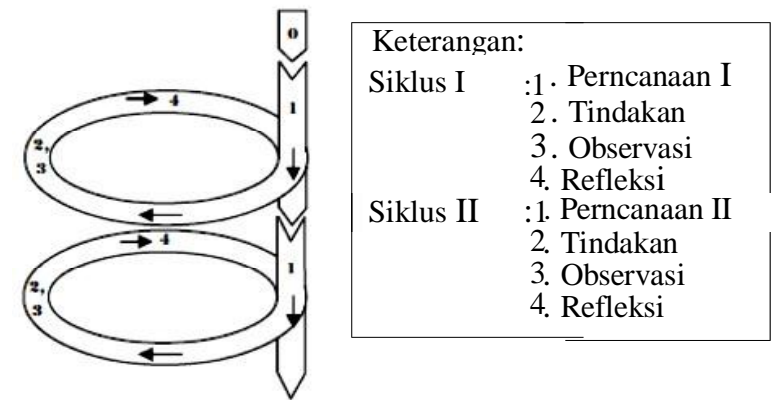

Gambar 1 Model Penelitian Kemmis dan Mc Tagggart (Arikunto, 2015, p. 84)

Penelitian Tindakan Kelas merupakan usaha para pendidik untuk memperbaiki pendidikan, terutama menjawab permasalahan yang terjadi dalam proses pembelajaran, sehingga dapat membuat guru menjadi kritis dan peka terhadap dinamika pembelajaran di kelasnya. Hal ini dipertegas oleh pernyataan (Cahyono et al., 2019) bahwa kualitas pembelajaran dapat dilihat dari peningkatan pengetahuan, keterampilan, dan pengembangan sikap melalui proses pembelajaran.

Teknik pengumpulan data dilkukan dengan teknik tes dan teknik non-tes. Instrumen penelitian adalah suatu alat yang digunakan mengukur fenomena alam 
maupun sosial yang diamati (Sugiyono, 2008, p. 148). Peneliti menggunakan lembar observasi, pedoman wawancara, angket respon siswa dan dokumentasi, Teknis analisis data yang digunakan yaitu dengan cara mencari nilai rata-rata siswa sebagai persentase hasil belajar.

Data penelitian ini diperoleh dari data hasil dan data proses pengamatan. Data hasil diperoleh dari tes menulis pantun, sedangkan data proses didapatkan dari observasi guru dan siswa. Pengecekan keabsahan data penelitian peningkatan keterampilan menulis pantun dengan menggunakan pendekatan contextual teaching and learning (CTL) berbantuan media kartu katadapat dilakukan dengan tiga cara, yaitu ketekunan pengamatan, pemeriksaan sejawat, dan triangulasi. Triangulasi pada penelitian ini dilihat dari perbandingan data yang diperoleh dari tahap prasiklus, pelaksanaan siklus I, dan siklus II.

\section{Hasil dan Pembahasan}

Dalam penelitian ini, penggunaan media lebih ditujukan untuk menggali ide untuk membuat kalimat-kalimat yang akan disusun menjadi pantun. Hal ini sejalan dengan ciri pembelajaran bahasa yang seharusnya mampu membentuk kompetensi komunikatif pada diri siswa. Tidak hanya sekedar pada penguasaan struktur dan bentuk bahasa.

Kartu kata mampu menerjemahkan ide-ide abstrak tentang keterampilan menulis pantun menjadi bentuk yang lebih realistik dengan menambahkan contoh pantun sesuai ide kata ide gambar. Hal ini sejalan dengan pendapat (Sudjana, 2013) bahwa kartu kata dapat membantu siswa mengembangkan kemampuan berbahasa, kegiatan seni, dan pernyataan kreatif dalam bercerita, dramatisasi, bacaan, penulisan, melukis dan menggambar, serta membantu mereka menafsirkan dan mengingat-ingat isi materi bacaan dalam buku teks.

Media kartu kata yang digunakan juga bertujuan agar siswa lebih memusatkan perhatian dan tidak merasa jenuh selama pembelajaran berlangsung. (Arsyad, 2014, p. 15) berpendapat bahwa pemakaian media pembelajaran dalam proses belajar mengajar dapat membangkitkan keinginan dan minat yang baru, membangkitkan motivasi dan rangsangan kegiatan belajar, dan bahkan membawa pengaruh-pengaruh psikologis terhadap siswa.

Peningkatan hasil evaluasi pada siklus I terjadi karena peneliti menerapkan penggunaan media kartu kata dalam proses pembelajarn. Kegiatan diawali dengan membuat siswa senang dengan pantun dengan menuliskan puisi, menyanyikan lagu yang syairnya mengandung pantun dan yang bukan pantun. Guru menyampaikan tujuan pembelajaran dan memberikan penjelasan materi pembelajaran sebelum pemberian tugas. Guru juga menggunakan metode diskusi kelompok agar siswa dapat bekerja sama dan saling berbagi pengetahuan dalam menyelesaikan tugas.

Penambahan teks kosa kata pada katu kata dalam pembelajaran mempermudah siswa memahami aturan penulisan dan ciri-ciri pantun. Guru menggunakan kartu kata tentang kegiatan siswa yang mengikuti aturan. Beberapa kartu kata dicetak dalam kertas bervariasi warna yang dibelakangnya terdapat pantun acak yang harus disusun siswa. Penggunaan kartu kata sejalan dengan pendapat (Sudjana, 2013) bahwa kartukata membantu mendorong para siswa dan dapat membangkitkan minatnya pada pelajaran.

Jumlah siswa dalam kelompok yang terlalu banyak juga menyebabkan siswa bercerita, bermain-main dan tidak ikut mengerjakan tugas. Hal ini menyebabkan keterampilan siswa dalam menulis pantun tidak terasah. Padahal pengembangan keterampilan menulis sangat memerlukan praktek dan latihan. Adapun deskripsi peningkatan hasil penelitian tersebut dapat diuraikan sebagai berikut. 


\section{Peningkatan Keterampilan Guru Siklus I dan II}

Keterampilan guru dalam mengelola pembelajaran menulis pantun menggunakan pendekatan CTL berbantuan kartu kata pada siklus I pertemuan kesatu mencapai skor 27, kemudian pada siklus I pertemuan kedua meningkat menjadi 29 sehingga rata-rata skor pada siklus I adalah 28 dengan persentase keberhasilan sebesar $72,5 \%$. Pada siklus II pertemuan kesatu skor keterampilan guru mencapai 33 dan meningkat pada siklus II pertemuan kedua menjadi 37 sehingga rata-rata skor keterampilan guru pada siklus II adalah 35 dengan persentase keberhasilan sebesar $92,5 \%$. Dari hasil observasi tersebut, diketahui bahwa terjadi peningkatan keterampilan guru pada siklus I ke siklus II. Berdasarkan peningkatan tersebut, keterampilan guru dalam pembelajaran bahasa Indonesia telah mencapai kategori baik.

Keterampilan guru dalam melaksanakan prapembelajaran pada siklus I pertemuan kesatu memperoleh skor 27 dengan kategori baik. Pada indikator Guru menjelaskan cara menulis pantun dengan runtut dan mudah difahami; membimbing siswa menemukan kata akhir bagian isi pantun melalui kartu kata; membimbing siswa mencocokkan persajakan; belum maksimal pada pertemuan kesatu ini dan akan diperbaiki pada pertemuan kedua siklus I. Pada siklus I pertemuan kedua skor meningkat menjadi 29 dengan kategori baik. Pada siklus II pertemuan lebih memaksimalkan pada indikator membimbing siswa mencocokkan persajakan; membimbing siswa membuat kalimat pantun; membantu siswa memperbaiki pantun; memberi kesempatan siswa membacakan pantun. Pada siklus II pertemuan kesatu skor meningkat menjadi 33 dengan kategori sangat baik. Pada siklus II pertemuan kedua skor meningkat menjadi 37 dengan kategori sangat baik

Keterampilan guru dalam melaksanakan pembelajaran sejalan dengan salah satu tujuan dalam membuka pelajaran sesuai dengan Permendiknas Nomor 41 Tahun 2007 yaitu menyiapkan siswa secara psikis dan fisik untuk mengikuti proses pembelajaran. Secara garis besarnya, keterampilan guru dalam mengelola pembelajaran menulis pantun menggunakan pendekatan CTL berbantuan kartu kata mengalami peningkatan dari siklus I ke siklus II, hal tersebut terbukti dari hasil pengamatan indikator keterampilan guru yang sudah diuraikan diatas.

Adapun kajian empiris berupa penelitian yang mendukung peningkatan keterampilan guru menggunakan model CTL adalah penelitian yang dilakukan oleh Anggriawan Nova Prasetya dkk. pada tahun 2013 dengan judul "Penggunaan Pendekatan Kontekstual dalam Peningkatan Kemampuan Menulis Puisi Siswa Kelas V Sekolah Dasar". Hasil penelitian tersebut menunjukkan bahwa terdapat peningkatan keterampilan guru dalam pelaksanaan pembelajaran pada tiap siklusnya yaitu pada siklus I mencapai $65,47 \%$, siklus II $77,38 \%$ dan siklus III mencapai $87,51 \%$. Oleh karena itu, peneliti menyimpulkan bahwa pendekatan CTL berbantuan kartu kata dapat meningkatkan keterampilan guru dalam mengelola pembelajaran menulis pantun.

\section{Peningkatan Aktivitas Siswa Siklus I dan II}

Aktivitas siswa dalam kegiatan pembelajaran menulis pantun melalui pendekatan CTL berbantuan kartu kata pada siklus I pertemuan kesatu mencapai skor 62,4 kemudian pada siklus I pertemuan kedua meningkat menjadi 70 sehingga ratarata skor pada siklus I adalah 66,2 dengan persentase keberhasilan sebesar $60 \%$. Pada siklus II pertemuan kesatu skor aktivitas siswa mencapai 73,5 dan meningkat pada siklus II pertemuan kedua menjadi 74,59 sehingga rata-rata skoraktivitas siswa pada siklus II adalah 74,1 dengan persentase keberhasilan sebesar $85 \%$. Dari hasil observasi tersebut, diketahui bahwa terjadi peningkatan aktivitas siswa pada siklus I ke siklus II. Berdasarkan peningkatan tersebut, aktivitas siswa dalam pembelajaran bahasa Indonesia telah mencapai kategori sangat baik. 
Pada aspek aktivitas siswa dalam menyiapkan diri untuk mengikuti pelajaran pada pelaksanaan tindakan siklus I pertemuan kesatu memperoleh rata-rata skor 62,4 , aktivitas siswa yang tampak yaitu siswa mendengarkan penjelasan guru; siswa serius mengamati media kartu kata;, kemudian menyiapkan buku dan alat tulis yang akan digunakan selama pembelajaran. Pada siklus I pertemuan kedua perolehan rata-rata skor meningkat menjadi 70, seluruh siswa tampak berani bertanya ketika mengalami kesulitan dalam pembelajaran. Pada siklus II pertemuan kesatu perolehan rata-rata skor menjadi 73,5. Kemudian pada siklus II pertemuan kedua perolehan rata-rata skor meningkat kembali menjadi 74,59 namun pada aspek siswa berani bertanya ketika mengalami kesulitan dalam pembelajaran, dan siswa serius dalam mengoreksi pantun yang ditulis belum maksimal. Kegiatan yang dilakukan siswa dalam menyiapkan diri untuk mengikuti pelajaran tersebut berhubungan dengan faktor yang dapat mempengaruhi proses belajar siswa menurut (Mustaqim \& Wahab, 2010), yaitu kondisi fisik orang yang belajar, kondisi psikis anak, kemauan belajar, dan sikap terhadap guru merupakan beberapa faktor yang memberikan kontribusi terhadap kualitas pembelajaran untuk mencapai tujuan belajar.

Aktivitas siswa ketika menanggapi apersepsi yang dilakukan guru untuk membangun pengetahuan awal yang dimilikinya terkait materi pantun pada siklus I pertemuan kesatu belumtampak. Hal tersebut disebabkan karena sedikitnya siswa yang tampak menanggapi apersepsi terkait pengetahuan awal yang dimilikinya serta menjawab pertanyaan guru untuk membanguan konsep awal terkait ciri-ciri pantun, siswa juga belum tampak menanggapi tujuan pembelajaran yang disampaikan guru atau bertanya terkait materi yang akan dipelajari. Namun pada siklus I pertemuan kedua terjadi peningkatan jumlah siswa yang tampakmenanggapi apersepsi terkait pengetahuan awal yang dimilikinya serta menjawab pertanyaan guru untuk membanguan konsep awal terkait materi pantun sudah ada peningkatan. Kemudian pada siklus II pertemuan kesatu sebagian siswa menanggapi tujuan pembelajaran yang disampaikan guru juga semakin mmeningkat.. Pada siklus II pertemuan kedua beberapa siswa tampak bertanya terkait materi yang akan dipelajari sehingga rata-rata skor aktivitas siswa meningkat. Kegiatan apersepsi yang dilakukan guru tersebut sesuai prinsip pembelajaran kontruktivisme menurut (Hosnan, 2014, p. 270) bahwa dalam proses pembelajaran siswa perlu membangun pemahamannya sendiri berdasarkan pengetahuan yang sudah dimiliki secara aktif, kreatif, dan produktif.

Kemampuan siswa dalam mengidentifikasi bagian pantun untuk menemukan ciri-ciri pantun pada siklus I pertemuan kesatu belum maksimal. Hal tersebut disebabkan karena sebagian besar siswa belum mengungkapkan hasil temuannya dengan tepat serta belum tampak siswa yang mengajukan pertanyaan. Kemudian pada siklus I pertemuan kedua sebagian besar siswa tampak mengidentifikasi permasalahan yang diberikan oleh guru, aktif mengeluarkan pendapat dan mengungkapkan hasil temuannya dengan tepat serta tampak 2 siswa mengajukan pertanyaan. Aktivitas siswa pada siklus II pertemuan kesatu mengalami peningkatan. Keadaan tersebut ditunjukkan dengan bertambahnya jumlah siswa yang mengajukan pertanyaan. Pada siklus II pertemuan kedua jumlah siswa yang mengajukan pertanyaan semakin bertambah dari pertemuan sebe-lumnya. Kemampuan siswa dalam melalakukan kegiatan menemukan pengetahuan baru tersebut selaras dengan prinsip keterlibatan langsung atau berpengalaman dalam kegiatan belajar menurut Dimyati dan Mudjiono (2013:4249) yaitu dalam belajar melalui pengalaman langsung siswa belum sekedar mengalami secara langsung tetapi harus menghayati, terlibat langsung dalam perbuatan, dan bertanggung-jawab terhadap hasilnya.

Kemampuan siswa dalam menjawab pertanyaan dan bertanya berdasarkan ciri-ciri pantun yang ditemukannya pada siklus I pertemuan kesatu belum nampak. Beberapa siswa belum aktif dalam kegiatan tanya jawab sehingga belum dapat menyimpulkan materi tentang pantun. Kemudian siklus I pertemuan kedua mengalami 
peningkatan. Keadaan tersebut ditunjukkan dengan bertambahnya jumlah siswa yang aktif dalam kegiatan tanya jawab. Pada siklus II pertemuan kesatu rata-rata skor meningkat Keadaan tersebut ditunjukkan dengan bertambahnya jumlah siswa yang aktif dalam kegiatan tanya jawab dan menyimpulkan materi. Pada siklus II pertemuan kedua sebagian besar siswa aktif mengangkat tangan dalam kegiatan tanya jawab dan menjawab pertanyaan guru berdasarkan pengetahuan baru yang ditemukan terkait pantun dengan tepat, siswa tersebut kemudian menjelaskan hubungan antara konsep yang ditemukan saat mengidentifikasi masalah terkait ciri-ciri pantun dengan konsep pada ciri-ciri pantun secara umum sehingga rata-rata skor aktivitas siswa meningkat. Sejalan dengan kegiatan bertanya menurut (Hosnan, 2014, p. 270) bahwa dalam proses pembelajaran, guru tidak hanya menyampaikan informasi begitu saja, tetapi memancing agar siswa dapat sebuah pengetahuan baru melalui sebuah pertanyaan agar siswa aktif dan berpikir kritis.

Dalam melaksanakan kegiatan belajar secara berkelompok, aktivitas siswa pada siklus I pertemuan kesatu belummaksimal. Beberapa siswa belum memperhatikan penjelasan guru dengan baik terkait aturan diskusi sehingga ketika melaksanakan kegiatan diskusi belum maksimal. Pada siklus I pertemuan kedua sebagian besar siswa saling kerjasama dalam diskusi kelompok meningkat dan pada siklus II pertemuan kesatu siswa mulai terkondisi dengan baik dalam kegiatan belajar kelompok meningkat. Pada siklus II pertemuan kedua, seluruh siswa tampak tampak memperhatikan penjelasan guru terkait aturan dalam diskusi, kerjasama untuk memecahkan masalah, menulis hasil diskusi, dan menyelesaikan kegiatan diskusi tepat waktu. Aktivitas siswa dalam kegiatan belajar secara berkelompok tersebut selaras dengan kegiatan dalam masyarakat belajar menurut Sardiman (2011:225) yaitu tukar pendapat antar teman, antar kelompok, dan antar yang tahu kepada yang belum tahu.

Aktivitas siswa saat memperhatikan materi yang disampaikan oleh guru pada siklus I pertemuan kesatu masih belumnampak. Beberapa siswa masih belum tampak menyimak penjelasan guru, mencatat hal-hal yang penting, dan tampak bermain sendiri atau bermain dengan temannya. Kemudian siklus I pertemuan kedua mengalami peningkatan. Keadaan tersebut ditunjukkan dengan bertambahnya jumlah siswa yang tampak menyimak penjelasan guru dan mencatat hal-hal yang penting. Pada siklus II pertemuan kesatu semakin baik. Keadaan tersebut ditunjukkan dengan bertambahnya jumlah siswa yang tampak menyimak penjelasan guru. Pada siklus II pertemuan kedua sebagian besar siswa menunjukkan sikap duduk yang baik, menyimak penjelasan guru, mencatat hal-hal yang penting, dan tidak bermain sendiri atau bermain dengan temannya .Sejalan dengan teori pembelajaran dalam Permendikbud Nomor 103 tahun 2014 yaitu pembelajaran merupakan proses interaksi antar siswa dan antara siswa dengan guru serta sumber belajar pada suatu lingkungan belajar.

Kemampuan siswa ketika mempresentasikan hasil diskusi pada siklus I pertemuan kesatu masih perlu ditingkatkan. Rendahnya perolehan skor disebabkan karena sedikitnya siswa yang tampak maju ke depan kelas untuk menyampaikan hasil temuannya dengan suara yang jelas dan lantang. Pada siklus I pertemuan kedua, aktivitas siswa mengalami peningkatan. Beberapa siswa tampak maju ke depan kelas untuk menyampaikan hasil temuannya dengan suara yang jelas dan lantang. Kemudian pada siklus II pertemuan kesatu ,sebagian siswa tampak maju ke depan kelas untuk menyampaikan hasil temuan dengan suara yang jelas dan lantang. Pada siklus II pertemuan kedua rata-rata skor aktivitas siswa meningkat. Beberapa siswa tampak menanggapi hasil presentasi temannya. Kemampuan siswa dalam melaksanakan permodelan tersebut selaras dengan pengertian permodelan dalam kegiatan belajar menurut (Hosnan, 2014, p. 272) yaitu pemberian contoh tentang cara 
mengoperasikan sesuatu, menunjukkan hasil karya atau mempertontonkan suatu penampilan.

Kegiatan siswa dalam melakukan refleksi terhadap hasil pembelajaran pada pelaksanaan tindakan siklus I pertemuan kesatu masih rendah.. Rendahnya perolehan skor disebabkan karena siswa belum tampak bertanya tentang hal-hal yang belum dipahami terkait materi pembelajaran yang telah dilaksanakan serta sebagian besar siswa belum tampak mencatat hasil rangkuman pada buku catatan. Sedangkan pada siklus I pertemuan kedua belum tampak kegiatan tanya jawab terkait materi pembelajaran yang sudah dilakukan. Pada siklus II pertemuan kesatu ada peningkatan. Keadaan tersebut ditunjukkan dengan peningkatan jumlah siswa yang mencatat hasil rangkuman pada buku catatan. Kemudian pada siklus II pertemuan kedua sebagian besar siswa tampak menjawab pertanyaan guru dengan tepat, ikut berpartisipasi aktif dalam menyimpulkan materi pembelajaran di bawah bimbingan guru, serta mencatat hasil rangkuman pada buku catatannya. Kegiatan siswa dalam melakukan refleksi tersebut merupakan cara berpikir atau perenungan tentang apa yang baru dipelajari atau berpikir ke belakang tentang apa-apa yang sudah dilakukan atau dipelajari(Sardiman, 2014, p. 277).

Pada aspek aktivitas siswa dalam mengerjakan tes evaluasi pada siklus I pertemuan kesatu beberapa siswa belum menyelesaikan evaluasi tepat waktu. Siklus I pertemuan kedua mengalami peningkatan. Pembelajaran dengan pendekatan kotekstual menuntut siswa aktif dalam pembelajaran (Yusro, 2015). Keadaan tersebut ditunjukkan dengan bertambahnya siswa yang menyelesaikan evaluasi tepat waktu. Kemudian pada siklus II (pertemuan kesatu dan kedua) Seluruh siswa tampak menyimak petunjuk dan arahan dari guru terkait aturan dalam mengerjakan soal evaluasi kemudian mengerjakan evaluasi secara individu, tidak menyontek, dan menyelesaikan evaluasi tepat waktu. Aktivitas siswa dalam mengerjakan tes evaluasi selaras dengan dua faktor yang mempengaruhi belajar menurut (Mustaqim \& Wahab, 2010), yaitu kemampuan bawaan anak dan ulangan sebagai alat ukur siswa terhadap hasil pembelajaran yang telah dilakukan. Secara garis besarnya, aktivitas siswa dalam proses pembelajaran menulis pantun melalui pendekatan CTL berbantuan kartu kata mengalami peningkatan dari siklus I ke siklus II, hal tersebut terbukti dari hasil pengamatan aktivitas siswa yang sudah diuraikan diatas.

Adapun kajian empiris berupa penelitian yang mendukung peningkatan aktivitas siswa melalui model CTL adalah penelitian yang dilakukan oleh (Kusumawati, 2016) hasil penelitian menunjukkan bahwa: (1) keterampilan guru pada siklus I memperoleh skor 29,5 dalam kategori baik, siklus II meningkat menjadi 33,5 dalam kategori sangat baik; (2) aktivitas siswa pada siklus I memperoleh skor 23,9 dalam kategori baik, siklus II meningkat menjadi 29,5 dalam kategori baik; (3) keterampilan menulis pantun siswa pada siklus I memperoleh rata-rata skor 70,8 dengan persentase ketuntasan $66 \%$, siklus IIrata-rata skor meningkat 83,4 dengan persentase ketuntasan $79 \%$. Oleh karena itu, peneliti menyimpulkan bahwa penggunaan pendekatan CTL berbantuan kartu kata dapat meningkatkan aktivitas siswa dalam pembelajaran menulis pantun.

\section{Peningkatan Keterampilan Menulis Pantun Siswa Siklus I dan II}

Keterampilan menulis merupakan proses dimana siswa belajar mengembangkan keterampilan dan kreativitasnya dalam menulis berdasarkan pengalaman yang dimiliki. Hal tersebut sejalan dengan Hakim (dalam Hamdani, 2011:21) yang menyatakan bahwa belajar merupakan suatu proses perubahan dalam kepribadan manusia, dan perubahan tersebut ditampakkan dalam bentuk peningkatan kualitas dan kuantitas tingkah laku seperti peningkatan kecakapan, pengetahuan, pemahaman, keterampilan, daya pikir, dan lain-lain.

Berdasarkan skor hasil belajar menulis pantun yang diperoleh siswa, dapat diketahui bahwa rata-rata skor hasil belajar siswa pada sebelum tindakan adalah 52,70

Penggunaan Contextual Teaching... (S Suprapto, V. Teguh Suharto, dan Lulus Irawati) 
dengan persentase ketuntasan belajar klasikal sebanyak $45 \%$ kemudian meningkat pada siklus I menjadi 72,30 dengan persentase ketuntasan belajar klasikal sebanyak $60 \%$. Pada siklus II rata-rata skor hasil belajar siswa mengalami peningkatan lagi menjadi 86,35 dengan persentase ketuntasan belajar klasikal yang telah mencapai $85 \%$.

Sebelum tindakan terdapat 13 siswa yang belum tuntas dengan prersentase $65 \%$.Siswa yang tuntas ada 7 siswa dengan persentase $35 \%$. Pada siklus I siswa yang belum tuntas ada 8 siswa dengan persentase 40\% dan yang sudah tuntas 12 siswa dengan persentase $60 \%$. Terjadi penurunan jumlah siswa yang belum tuntas sebanyak 5 siswa dengan persentase $25 \%$. Siswa yang tuntas mengalami kenaikan dari 7 siswa menjadi 12 siswa atau mengalami peningkatan $25 \%$. Pada siklus II siswa yang belum tuntas ada 3 siswa dengan persentase $15 \%$ dan yang sudah tuntas 17 siswa dengan persentase $85 \%$. Terjadi penurunan jumlah siswa yang belum tuntas sebanyak 5 siswa dengan persentase $25 \%$. Siswa yang tuntas mengalami kenaikan sebanyak 5 siswa, dari 12 siswa menjadi 17 siswa atau mengalami peningkatan $25 \%$.

Adapun kajian empiris berupa penelitian yang mendukung peningkatan keterampilan menulis pantun melalui pendekatan CTL berbantuan kartu kata adalah penelitian yang dilakukan oleh Penelitian (Subekti, 2015) mengemukakan bahwa dengan peningkatan hasil pembelajaran tersebut meliputi peningkatan keterampilan dalam menulis pantun dengan aspek keterampilan menentukan tema pantun yang sesuai dengan gambar.

Hasil penelitian menunjukkan adanya peningkatan. Pada pratindakan, siswa yang mencapai nilai KKM sebanyak 10 siswa atau 27,03\% dengan nilai rata-rata kelas 54,50 . Setelah dilakukan tindakan, siswa yang tuntas mengalami peningkatan menjadi 28 siswa atau $75,68 \%$ dengan nilai rata-rata kelas 76,49. Hasil tersebut juga menunjukkan adanya pengaruh penerapan kartu kata terhadap peningkatan kemampuan menulis siswa dalam proses pembelajaran pada kelas yang menerapkan media kartu kata dibanding kelas biasa. Oleh karena itu, peneliti menyimpulkan bahwa pendekatan CTL berbantuan kartu kata dapat meningkatkan hasil belajar siswa pada keterampilan menulis pantun.

\section{Kesimpulan}

Hasil keterampilan menulis pantun dengan pendekatan Penggunaan Pendekatan Contextual Teaching and Learning (CTL) Berbantuan Media Kartu Kata Untuk Meningkatkan Keterampilan Menulis Pantun Pada Siswa Kelas V SDN 2 Ngrayun Ponorogo juga mengalami peningkatan. Peningkatan keterampilan menulis pantun dilihat dari peningkatan nilai menulis pantun setiap siklus. Nilai rata-rata siswa sebelum penelitian adalah 52,7 . Pada Siklus I nilai rata-rata siswa naik sebesar $25 \%$ menjadi 72,3 . Pada Siklus II nilai rata-rata siswa naik $25 \%$ menjadi 86,35. Dari 20 siswa Kelas $V$ sebanyak 17 siswa atau $85 \%$ siswa mendapat nilai menulis pantun di atas kriteria ketuntasan minimal. Berdasarkan hasil penelitian, didapatkan tiga hal atau saran: Peneliti menemukan lima dari 20 siswa mengalami fluktuasi nilai dalam menulis pantun. Karena keterbatasan waktu dalam penelitian, maka faktor penyebab timbulnya fluktuasi nilai dari kelima siswa tersebut di atas belum dapat diungkapkan. Hal ini merupakan peluang bagi peneliti selanjutnya yang tertarik pada penelitian menulis pantun dengan pendekatan Contextual Teaching and Learning (CTL) Berbantuan Media Kartu Kata. Bagi peneliti lain, penelitian ini dapat referensi atau rujukan melakukan penelitian lanjut penerapan pendekatan Contextual Teaching and Learning (CTL) Berbantuan Media Kartu Kata pada keterampilan menulis lainya. Bagi guru kelas atau mata pelajaran bahasa Indonesia, pendekatan Contextual Teaching and Learning (CTL) Berbantuan Media Kartu Kata.dapat menjadi alternatif dalam pembelajaran menulis pantun. 


\section{Daftar Pustaka}

Arikunto, S. (2015). PenelitianTindakan Kelas. Bumi Aksara.

Arsyad, A. (2014). Media Pembelajaran. Raja Grafindo Persada.

Cahyono, B. E. H., Irawati, L., \& Candrawati, D. T. (2019). Implementasi Model Pembelajaran Rekreasi-Prokreasi dalam Membaca Kritis Teks Eksplanasi di SMK. Indonesian Language Education and Literature, 5(1), 61. https://doi.org/10.24235/ileal.v5i1.5032

Hosnan, H. (2014). Pendekatan Saintifik dan Kontekstual dalam Pembelajaran Abad 21. Ghalia Indonesia.

Kadarusman, G., \& Cahyono, B. E. H. (2018). Penggunaan Media Pembelajaran Pohon Ajaib dengan Model Pembelajaran Make A Match untuk Meningkatkan Penguasaan Kosa Kata Bahasa Indonesia Siswa Tunarungu Kelas II SDLB Dharma Wanita Jiwan Kabupaten Madiun. Linguista: Jurnal Ilmiah Bahasa, $\begin{array}{llll}\text { Sastra, Dan } & \text { Pembelajarannya, }\end{array}$ https://doi.org/10.25273/linguista.v2i1.2756

Kemmis, S., \& McTaggart, R. (1988). The Action research planner (3rd ed.). Deakin University.

Kusumawati, L. D. (2016). Peningkatan Keterampilan Menulis Pantun melalui Model Contextual Teaching and Learning Berbantuan Kartu Kata pada Siswa Kelas IV-B SD Labschool Unnes. UNNES.

Mustaqim, M., \& Wahab, A. (2010). Psikologi Pendidikan. Rineka Cipta.

Rifa'i, R., \& Anni, A. (2011). Psikologi Pendidikan. UPT UNNES PRESS.

Rosmayanti, E. (2010). Pengaruh Lagu Anak Anak Terhadap Kreativitas Menulis Puisi Siswa sekolah Dasar. UPI.

Rusman, R. (2014). Model-Model Pembelajaran Mengembangkan Profesionalisme Guru. Rajawali Press.

Sardiman, S. (2014). Interaksi Dan Motivasi Belajar Mengajar. Rajawali Press.

Subekti, A. (2015). Upaya Meningkatkan Keterampilan Menulis Pantun Dengan Menggunakan Media Gambar Pada Siswa Kelas IV SD Negeri Nglarang Sleman. Universitas NEgeri Yogyakarta.

Sudjana, N. (2013). Penilaian Hasil Proses Belajar Mengajar. Remaja Rosda Karya.

Sugiyono, S. (2008). Metode penelitian pendidikan:(pendekatan kuantitatif, kualitatif dan $R \& D)$. Alfabeta.

Supriyadi, S. (2016). Pembelajaran Sastra yang Apresiatif dan Integratif di Sekolah Dasar. Departemen Pendidikan Nasional.

Susilowati, D. (2018). Penelitian Tindakan Kelas (PTK) Solusi Alternatif Problematika Pembelajaran. Jurnal Ilmiah Edunomika, 2(01), 36-46. https://doi.org/10.29040/jie.v2i01.175

Wardana. (2017). Potensi Dan Strategi Pengembangan Pariwisata Di Kabupaten Pesisir Barat. 1-78.

Yusro, A. C. (2015). Pengembangan Modul Pembelajaran Fisika Berbasis Kontekstual yang Terintegrasi dengan Website pada Siswa Kelas XI IA SMA Negeri 5 Madiun Tahun Ajaran 2012/2013. Univesitas Sebelas Maret. 